\title{
Competence development as normative practice - Educational reform in medicine as heuristic model to relate worldview and education
}

\begin{abstract}
Author:
Gerrit Glas ${ }^{1}$

Affiliation:

${ }^{1}$ Faculty of Philosophy, Vrije

Universiteit, The Netherlands

Correspondence to:

Gerrit Glas

Email:

glasg@xs4all.nl

\section{Postal address:}

De Boelelaan 1105, 1081 HV

Amsterdam, The Netherlands

\section{Dates:}

Received: 18 Mar. 2012

Accepted: 13 Sept. 2012

Published: 05 Dec. 2012

How to cite this article: Glas, G., 2012, 'Competence development as normative practice - Educational reform in medicine as heuristic model to relate worldview and education', Koers - Bulletin for Christian Scholarship 77(1), Art. \#411, 6 pages. http://dx.doi. org/10.4102/koers.v77i1.411

\section{Note:}

This article was developed from a paper delivered at the Koers-75 Conference on 'Worldview and Education', held in Potchefstroom, South Africa, from 30 May to 02 June 2011.

Hierdie artikel is ' $n$ verdere ontwikkeling van 'n voordrag gelewer by die Koers-75 Konferensie oor 'Worldview and Education' in Potchefstroom, Suid-Afrika, vanaf 30 Mei tot 02 Junie 2011.
\end{abstract}

In this article, a Normative Practice Model (NPM) for education was developed. Two hypotheses guided this article: (1) the presupposition that developments in medical education are relevant for education in general and (2) the idea that medical education, just as education in general, can be interpreted as a normative practice. The Normative Practice Model was initially designed for medicine. This original version attempted to clarify why norms and values are intrinsic to medical practice, what these norms and values are, and how they are related. This article introduced the recent reform of medical specialist training programmes in the Netherlands as a case study for application of the Normative Practice Model to education. This reform elucidates how and why norms and values are intrinsic to medical education. The Normative Practice Model offers a global framework that enables one to locate and evaluate the relative contribution of each of the norms and values. By doing so the model also gives an answer to the more general question of whether and how worldview and education are connected. It appears that in highly technical and specialised practices such as medicine, the concept of competence is used as bridge between valued-laden motivations and attitudes on the one hand and measurable performance on the other hand. In this article it was argued that thinking about competences in the context of normative practices helps to elucidate the relationship between worldview and education.

Bevoegdheidsontwikkeling as normatiewe praktyk - Onderwyshervorming in die geneeskunde as heuristiese model om werklikheidsbeskouing met onderwys in verband te bring. In hierdie artikel is ' $n$ normatiewe praktyk-model (NPM) vir die onderwys ontwikkel. Twee hipoteses het hierdie artikel gelei: (1) dat die ontwikkelinge in die mediese onderwys relevant vir onderwys in die algemeen is en (2) dat mediese onderwys, net soos algemene onderwys, as 'n normatiewe praktyk geïnterpreteer kan word. Die normatiewe praktyk-model is aanvanklik vir geneeskunde ontwerp. Hierdie oorspronklike weergawe het probeer om te verduidelik hoekom waardes en norme intrinsiek aan die mediese praktyk is, wat hierdie norme en waardes is en hoe hulle met mekaar verband hou. Die artikel stel die onlangse hervorming van opleidingsprogramme vir mediese spesialiste in Nederland as ' $n$ gevallestudie vir die toepassing van die normatiewe praktyk-model in die onderwys. Hierdie hervorming belig hoe en waarom norme en waardes intrinsiek aan mediese onderwys is. Die normatiewe praktyk-model bied ' $n$ globale raamwerk wat ' $n$ persoon in staat stel om die relatiewe bydrae van elk van die waardes en norme op te spoor en te evalueer. Deur dit te doen, bied die model ook ' $n$ antwoord op die meer algemene vraag of en hoe wêreldbeskouing en die onderwys verwant is. Dit blyk dat in hoogs tegniese en gespesialiseerde praktyke soos geneeskunde die bevoegdheid-konsep as brug tussen waarde-belaaide motivering en houdings aan die een kant en meetbare prestasie aan die ander kant dien. In hierdie artikel is geargumenteer dat nadenke oor bevoegdheid in die konteks van normatiewe praktyke help om die verhouding tussen werklikheidsbeskouing en die onderwys toe te lig.

\section{Medicine - Old and new needs and changing roles}

The need for the modernisation of the curricula of medical specialist training programmes that recently took place in the Netherlands had different sources. Firstly, for many decades patients have been asking for doctors who are not only technically and scientifically competent, but who are also able to communicate empathically, to organise their work and to collaborate properly. Patients tend to place high esteem on humanness and a certain level of wisdom. They have the desire to be understood. They ask for information that is to the point and at their own level of intellectual and emotional understanding. They prefer doctors who have the capacity to manage their time and who are flexible and creative in the delivery of care (Societal Needs Working Group 1996).
(C) 2012. The Authors. Licensee: AOSIS OpenJournals. This work is licensed under the Creative Commons Attribution License. 
Doctors, on the other hand, often struggle with time limits, production norms and institutional rules. Careful analysis of 'disasters' in medical practice has led to the observation that these disasters often result from insufficient collaboration and bad structuring of the process of delivery of care (Four UK Health Departments 2004). In short, medical educators have recognised that their curricula should not only be directed at the acquisition of knowledge and technical skills; thorough training in areas such as communication, collaboration and management should also be provided (Jones et al. 2001).

The reform in medical education coincided with another development in most of the Western countries, namely, the need to organise the delivery of health care in a cheaper and more efficient manner. For more than a decade, the government, insurance companies and patient organisations have been asking for a demand-driven (instead of supplydriven) care system and redefinition of professional roles and responsibilities in such a way that medical activities are performed at the lowest justifiable level of education and training (for the Dutch discussion see VWS 2002; VWS \& OCW 2003). The reform of medical education thus coincided with a rearrangement of the landscape of professions. This rearrangement has influenced professional roles as well. Medical specialists need to delegate more and more tasks to physician assistants, nurse practitioners and other professionals, but the increasing specialisation leads to a narrowing of focus. However, medical specialists remain responsible for the entire care delivery process.

The highest educated people in medicine tend to have the least contact with patients, but these same people are asked to overview the entire chain of care delivery. Although this is already complicated enough, the institutionalisation of health care currently adds to the complexity of professional roles. Medical professionals are no longer soloists working in relative isolation. They have to negotiate their roles in institutions offering them a working place. These institutions have their own dynamics - economic, legal, social, psychological, and societal (Freidson 2001). In short, the patient-physician relationship is currently not only influenced by new knowledge, redefinition of professional roles, and economic and legal factors. This relationship is also influenced by the interaction between the professional or groups of professionals and the management of their organisations.

\section{Towards a competence-based medical specialist training}

Until recently the traditional model of medical specialist training was based on the idea of learning by gradual immersion in clinical practice under the guidance of an experienced clinician. Modern theories of education underscore that other potential contributors to the learning process remain unused: learning by peers, structured feedback (tests, verbal feedback, multisource feedback), teaching others and the structuring influence of the learning environment itself.
For this reason, medical specialist organisations all over the world, especially in Canada, have reorganised their educational curriculum. In these reforms the concept of competence emerged as a new term, indicating that some capabilities of the doctor are latent - they do exist, but only come into expression under certain circumstances (Scheele et al. 2008).

What are competences? The briefest answer is that competences are capacities to act in specific situations. Or, less briefly, a competence is a capacity or disposition that integrates knowledge, skills and attitudes and that usually connects multiple domains of action. A surgeon who has acquired the capacity to perform an appendectomy (removal of the appendix) has knowledge about the intestines, the location of the intestines, the location of other vital structures in the environment (blood vessels, nerves), has acquired certain skills (the operating itself) and performs the operation with a certain attitude. The attitude can best be seen as the embodiment of certain values. The manner in which the operation is performed by the surgeon may, for instance, show goal-directedness and a certain amount of respect, thereby indicating that he or she has appropriated values such as responsible use of talent, means, time and reverence for the dignity of human life.

Epstein and Hundert (2002) summarise competence in a medical context in the following way:

Competence is the habitual and judicious use of communication, knowledge, technical skills, clinical reasoning, emotions, values and reflection in daily practice for the benefit of the individual and community being served. (n.p.)

Competences combine affect, cognition, disposition and action, and tend to have a practical focus. The intriguing characteristic about competences and dispositions is that often we cannot observe them; they are tacit, latent, just like certain character traits (shyness) are latent and only come to expression under certain circumstances (for instance, the presence of critical others). Evidence of competency is observed in practice by watching a person at work.

Another fascinating aspect is that competences are contextually sensitive. In other words, competences are not fixed habits that are released when someone presses a button. They are malleable, that is, the way they come to expression varies according to the needs of a particular situation. Discussing treatment options with a psychotic patient in psychiatry, for example, differs very much from context to context; it could take place in the office of a psychiatrist with a private practice, in a mental hospital, in the emergency unit of a hospital or at the police station.

The Canadian Medical Educational Directives for Medical Specialists (CanMEDS) describes seven roles or competences, namely, medical expert, communicator, collaborator, manager, health advocate, scholar and professional (see Figure 1) (Frank et al. 2005). Health advocacy refers to the competence of responsible behaviour at a societal level in the interest of the patient. This would include providing 
information to patient groups and third parties via advocacy in the public sphere, via professional organisations, in publications and social media, or, more directly, via personal contacts with key figures in politics, insurance companies and large organisations. Professionalism is a second order competence. It refers to the capacity to reflect on one's professional role, to define targets and to reach those targets. In the Netherlands and in other European countries the CanMEDS framework has been adopted for medical specialist training programmes.

One of the problems in the implementation of this framework has been the tension between competence as tacit capacity and competence as a term for a set of activities with a measurable performance. In other words, how can the presence of competences be tested and/or proven? Would this, once again, be by observing the trainee in clinical practice and by evaluating the level of integration of knowledge, skills and attitudes? Or would it be by using objective tests, detached from the context, that focus on observable behaviour and factual knowledge? Behind these two approaches lie two different views on the educational process, and, especially, its evaluation. The first approach is, generally, based on trust and presupposes a learning process of which the largest and most important part takes place implicitly, for example, by identification with role models. It places emphasis on integration. In other words, integrative capacities can be developed by practicing and problem solving, whether in real life or in representative learning environments, but not by absorbing information. The other approach is, again in general terms, based on suspicion. It says that the presence or absence of a competence should be measured more objectively and that competences should be operationalised

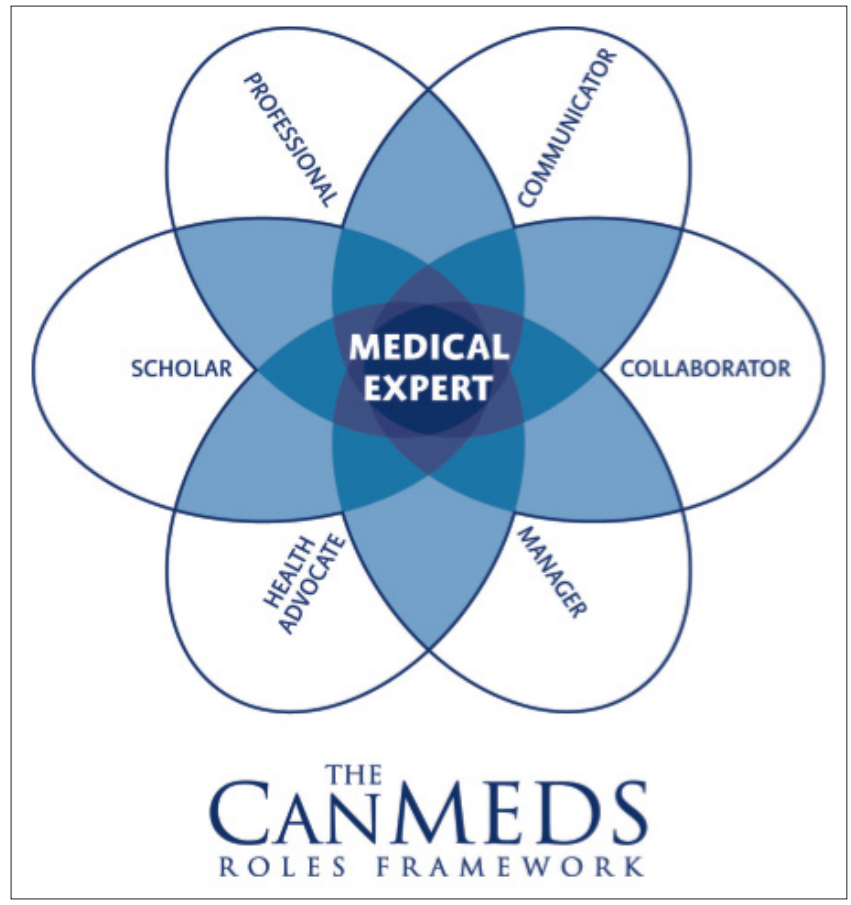

Source: Royal College, The CanMEDS 2005 Physician Competency Framework, viewed from http://www.royalcollege.ca/portal/page/portal/rc/common/documents/canmeds/ resources/publications/framework_full_e.pdf

FIGURE 1: CanMEDS roles for physicians. in such way that they are amenable for testing. In the practice of medical specialist training one usually finds a mix of both approaches. Training programmes typically try to keep a balance between practice-based learning with frequent and varied evaluations and more objective and structured evaluations via tests.

\section{Medical education as normative practice}

From a philosophical point of view, the recent advances in medical training are interesting. They represent a move away from an overly technical and knowledge-oriented approach of medical practice towards an approach that endeavours to integrate evidence-based knowledge and technical skills into a more holistic conception of medicine that gives communication, collaboration and organisation their due weight and pays attention to certain values that are (or, at least should be) inherent to professionalism. Think for instance of values like beneficence, judiciousness, respect and attunement of one's practice to the needs, not only of patients, but also of contexts at meso-levels (institutions) or macro-levels (society at large).

It is, in particular, the recognition of this value aspect which makes this educational reform interesting for the subject of this article, namely, the role of worldview in education. Values are embodied in attitudes, that is, the attitudes of the physician and of the educator. The new educational framework not only legitimises educators and trainees to absorb and appropriate these values but also invites them to make them explicit and to reflect on them. This ability requires capacity for self-reflection, which in turn forms part of the competence of professionalism. The self-reflection of the trainee is mirrored by the educator who adds new content and fresh perspectives to what the trainee makes explicit ('double loop learning'). The self-reflection of the educator may thereby serve as an example and point of reference.

There are some striking similarities between the ideas behind the medical educational reform just discussed and the idea of medicine as normative practice, as it has been developed by people like Henk Jochemsen, Jan Hoogland and myself (Jochemsen 2006; Jochemsen \& Glas 1997). The remainder of this article will thus investigate whether the idea of medicine as normative practice can be successfully applied to medical or other education. What are the issues laid bare by thinking about education as normative practice? What problems does it solve? Is there something new that can be elucidated?

\section{The Normative Practice Model}

The model was initially formulated in a book on the foundations of medicine and medical ethics (Jochemsen \& Glas 1997; cf. see also Polder, Hoogland, Jochemsen, Strijbos 1997, Hoogland \& Jochemsen 2000) and, later on, applied to the field of nursing, psychiatry and psychotherapy, media and communication, education and most recently developmental 
studies (Glas 2009; Jochemsen \& Hegeman 2011). The model grew out of dissatisfaction with principle-based approaches to ethics that reduce moral deliberation to the application of general moral principles or rules to practical situations. The deductive structure of this approach can also be recognised in older theological approaches to medical ethics. The problem with these principle-based approaches was that they were not able to do justice to the particularities of the moral situation, especially in highly technological practices. The principles were just too general and the moral practices too specialised and intricate. A further significant problem was that by placing moral principles above or outside medical practice, the impression was given that the moral dimension, instead of being a natural part of medical practice, should be added from outside. Ethics is then seen as a discipline foreign to medicine, whereas, in fact, the moral dimension can never be separated from the strictly medical.

Two ideas underpin the NPM that was developed as an alternative to these principles:

1. Norms are inherent to medical practice; they are not just abstract principles or metaphysical ideas. Norms belong to the practice itself in an intrinsic way, such that, when these norms are violated the identity of the practice itself is threatened.

2. These norms (values) show a certain order and qualify the practice in distinct ways, especially the relationships between the various actors in the field of medicine (patients, physicians, nurses, administrators, etc.).

The systematic philosophical background of these ideas can be found in the work of Dutch neo-Calvinist thinkers Herman Dooyeweerd (1894-1977) and Dirk Th. Vollenhoven (1892-1978), and some of their followers (Strauss 2009). Some of their most fundamental insights will now briefly be introduced.

The fundamental idea in this philosophy is:

1. that everything that exists functions in a plurality of modes (or ways of being; ways of functioning)

2. that none of these modes can be reduced to other modes

3. that, nevertheless, there exists a strong coherence between the modes.

There are, in other words, both diversity and coherence in the ways in which things exist or in their different modes of functioning. The psychic functioning of an individual cannot be reduced to the biotic functioning of that individual (the psychic function is irreducible), whereas, at the same time, this psychic functioning is completely interwoven with the biotic underpinnings of mental life.

Another important idea in this systematic philosophy is that things (events, processes) are characterised by a qualifying function. The qualifying function qualifies (characterises) the thing as it is. For example, inorganic entities (stones, rocks) are qualified by their physical function; plants by their biotic and animals by their psychic function, and so on. Apart from the qualifying function there is also a foundational function which indicates that the functioning of a certain thing depends on some other, more basic level of functioning. The ability to function in a foundational way means that in order for a particular thing to function, the operation of that foundational function is required. Without the opening up of the foundational function, that thing would not exist. Current medical practice, for instance, cannot be understood without the knowledge provided by scientific research and without the technical means and procedures that currently exist. Without such knowledge and technology medicine would not exist, only a dim and primitive precursor of it. Knowledge and technology do not qualify medical practice, they form its foundation. Qualifying medical practice lies in the nature of the patient-physician (or nurse) interaction, which is a moral one, because the interaction between patient and physician is characterised by beneficence on the part of the physician (or nurse) and by trust on the part of the patient.

A last important distinction is the one between structure and direction (Wolters 1985). There is a structural and a directional aspect to the way things develop over time. The structural aspect refers to the modal spheres (ways of functioning) in which a thing functions and the order and coherence between these spheres. The directional aspect refers to the fact that structures can be opened (i.e. put to work by human involvement). The process of civilisation is one grand attempt to open up hitherto closed functions. Human beings see relationships and possibilities beneath the appearance of things. For example, by trial and error people learn how things work, which directions for exploration are fruitful and which are not. In other words, they learn the regularities and relate them to the laws to which things obey. It was Dooyeweerd's contention that when parts of reality are opened up in a wrong (non-normative) direction, this will inevitably lead to antinomies (i.e. to tensions that will harm the development of that thing (process, larger whole). These tensions are the result of undue absolutisation of one of the functions (or aspects) of the thing. Absolutisation of the technical-formative aspect in medicine leads to the conception of the physician as engineer, and this overly technical approach leads to tensions in communication and collaboration with the patient. Not everything that is technically possible is to the benefit of the patient. Failing to negotiate properly about different treatment options leads to crises in the interaction between patient and physicians. These negotiations are, basically, negotiations about values (Woodbridge \& Fulford 2004).

One final remark about the model is that its development coincided with the resurgence of interest in virtue-ethics, mainly as a result of MacIntyre's landmark study After Virtue (MacIntyre 1981). This work depicted the good (or goods) as internal to practice and as embodied in standards of excellence, rules and codes of conduct. There are important points of convergence between the NPM and virtue-ethical approaches to medical ethics. However, without saying too much about it, it has to be questioned whether traditional virtue-ethics has the conceptual resources to give an account of the intrinsic normativity of highly technological contexts 
(whether in medicine or other sectors). Virtue-ethical approaches seem to work best in contexts that remain close to everyday life. This is because it is much more difficult to define goods internal to artificial practices than it is to describe intrinsic goods for everyday practices. The artificiality of the context detracts from the intrinsic nature of the goods. The Dooyeweerdian approach, with its intricate theory of opening-up of functions and its emphasis on the role of historical development in the opening-up of law-spheres, has more conceptual resources in this respect.

\section{Medicine as normative practice}

According to the view on normative practices propounded by Jochemsen \& Glas (1997), it is the moral sphere (the ethical modality) that should be considered as the leading or qualifying function of medicine as normative practice. This is because of the central importance of the value of beneficence which qualifies the doctor-patient relationship. The formative aspect has to be seen as foundational. Formation refers in this context to the development of techniques, skills and new (scientific) knowledge. Other aspects of medicine are neither qualifying nor foundational but conditional. They refer to the institutional, social (societal), economical and legal conditions that have helped to form medicine into the profession it is today.

Figure 2 shows in a schematic fashion how the NPM should be conceived when it is applied to medicine. The basic distinction is between the constitutive and the regulative side of medicine. The term constitutive means that the processes, events and interactions at this level establish (form, determine) the practice as the practice it is. Constitutive factors refer to the structure of medical practice, in other words, to that which medicine constitutes. We discern three types of factors (rules, norms): qualifying, foundational and conditioning factors. Qualifying rules or norms are those that determine medical practice proper; they make medicine into the moral endeavour it is. Conditioning rules and norms function as conditions; medical practice should obey certain social, legal, and economical rules and norms in order to maintain itself as practice. A foundational factor is the

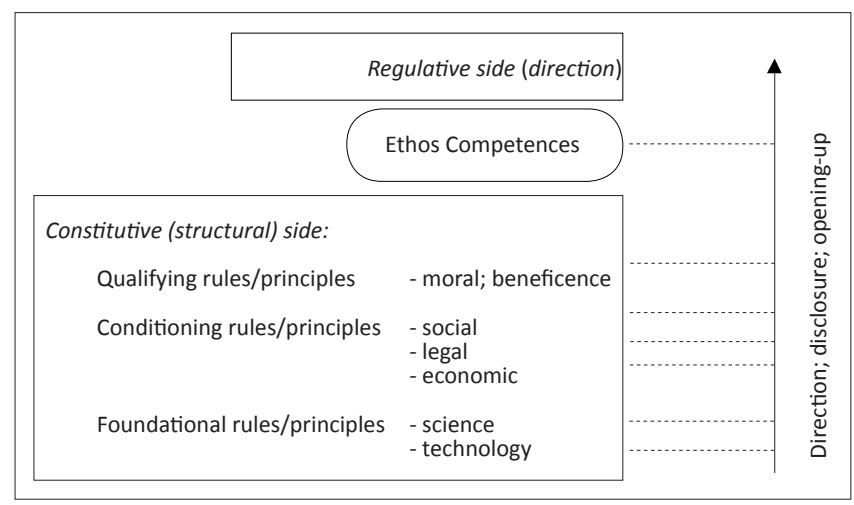

Source: Jochemsen, H., \& Glas, G., 1997, Verantwoord medisch handelen: Proeve van een Christelijke medische ethiek [Responsible medical conduct: Towards a Christian medical ethics], Buijten \& Schipperheijn, Amsterdam

FIGURE 2: Normative rules and principles for medical practice. historical development that has led to the incorporation of scientific insight and technical skill in medicine as practice.

The term regulative refers to the directional aspect or direction into which medical practice is moving. It refers to the religious, spiritual and existential dynamic that supports and influences this directedness and it is embodied in the ethos and implicit worldview of the profession, and in fundamental attitudes such as the non-selfish commitment of the physician. From an abstract point of view there are only two directions: one leading to the opening-up and flourishing of medicine as professional practice; and one leading to closure, one-sidedness and irresolvable tensions at the heart of medicine. In daily practice, the picture is usually more mixed, with tendencies towards growth and flourishing, as well as tendencies to fragmentation, tension and decay.

How do competences relate to these two sides? The author of this article has grown in the conviction that competences are not just technical skills that require operationalisation in learning situations. Competences can best be seen as rooted in existential soil and as having an intrinsic moral and/or spiritual value. Rather than separating competences as technical skills from the inner value-laden core of competences and of medical practice, the two (i.e. the moral (directional) and technical (structure) side of competences in medicine) should be seen as enmeshed and continuous. Thus conceived, the concept of competence has an important bridging function: it ties together the constitutive and the regulative side of medical practice. Communication, collaboration, management, scholarship and professionalism have a measurable, technical aspect. However, their essence cannot be understood without a proper sense of what medicine is meant for, in other words, without having an idea of what belongs to the core, the heart or soul, of medicine. This is the sustained endeavour to be beneficent, trustworthy and just, and to show respect, veracity and sincerity.

\section{Conclusion: Worldview and education}

The analysis of medicine as normative practice can help to create a clearer picture of education in a broader sense and in its relation to worldview. The main merits of the NPM are that (1) it elucidates why professionalism is not something neutral and (2) meaning and values are not added to a reality that is neutral in itself, but are already an intrinsic part of medical practices. Medical practice is by nature value laden. To deny this, is to make oneself vulnerable to uncritical acceptance of norms and values that may come along with new techniques or with dominant stakeholders, such as insurance companies, government authorities and/or the pharmaceutical industry.

Education in other fields than medicine can be construed along similar lines, that is, as practices with the ethical (moral) aspect as a qualifying function, with the historical formation of knowledge and skills as foundation, and with social, economic and legal norms and rules as conditional 
factors that help maintain the framework of education (i.e. its institutional, administrative and legal embedding).

The concept of competence binds the two sides together. Competence building has, apart from its structural side, an important regulative side. It is intrinsically normative in that at the end of the educational process the pupil should have embodied the values and knowledge that are intrinsic to the specific field of education. This normativity is, thus, constitutive for the practice for which education prepares the pupil. Normativity is not added from outside. Without it, education would not be what it is; it would lose its distinctive character.

\section{Acknowledgements Competing interests}

The author declares that he has no financial or personal relationship(s) which may have inappropriately influenced him in writing this article.

\section{References}

Epstein, R.M. \& Hundert, E.M., 2002, 'Defining and assessing professional competence', Journal of the American Medical Association 287, 226-235.

Four UK Health Departments, 2004, Modernising Medical Careers: The next steps. The future shape of Foundation, Specialist and General Practice Training Programmes, viewed 17 August 2012, from http://www.dh.gov.uk/prod consum dh/groups/ dh_digitalassets/@dh/@en/documents/digitalasset/dh_4079532.pd $\bar{f}$

Frank, J.R., Jabbour, M., Fréchette, D., Marks, M., Valk, N. \& Bourgeois, G. (eds.), 2005, 'Report of the CanMEDS Phase IV Working Groups', The Royal College of Physicians and Surgeons of Canada, Ottawa.

Freidson, E., 2001, Professionalism: The third logic, The University of Chicago Press, Chicago.
Glas, G., 2009, 'Modellen van 'integratie' in de psychologie en psychiatrie (II): Het normatieve praktijk model [Models of 'integration' in psychology and psychiatry: The normative practice model],' Psyche en Geloof 20, 165-177.

Hoogland, J. \& Jochemsen, H., 2000, 'Professional autonomy and the normative structure of medical practice', Theoretical Medicine 21, 457-475.

Jochemsen, H., 2006, 'Normative practices as an intermediate between theoretical ethics and morality', Philosophia Reformata 71, 96-112.

Jochemsen, H. \& Glas, G., 1997, Verantwoord medisch handelen: proeve van een christelijke medische ethiek [Responsible medical conduct: Towards a Christian medical ethics], Buijten \& Schipperheijn, Amsterdam.

Jochemsen, H., \& Hegeman, J., 2011, 'Connecting Christian faith and professional practice in a pluralist society', in B. De Muynck, J. Hegemann \& P. Vos (eds.), Bridging the Gap: Connecting Christian Faith and Professional Practice, pp. 73-86, Dordt College Press, Sioux Center.

Jones, R., Higgs, R., de Angelis C. \& Prideaux, D., 2001, 'Changing face of medical curricula', Lancet 357, 699-703.

Maclntyre, A., 1981, After virtue: A study in moral theory, University of Notre Dame Press, Notre Dame.

Polder, J.J., Hoogland, J., Jochemsen, H., Strijbos, S., 1997, 'Profession, practice, and profits: Competition in the core of health care system', Systems Research and Behavioural Science 14, 409-421.

Royal College, The CanMEDS, 2005 Physician Competency Framework, viewed from http://www.royalcollege.ca/portal/page/portal/rc/common/documents/ canmeds/resources/publications/framework_full_e.pdf

Scheele, F., Teunissen, P., Van Luijk, S., Heineman, E., Fluit, L., Mulder, H. et al., 2008 , 'Introducing competency-based postgraduate medical education in the Netherlands', Medical Teacher 30, 248-253.

Societal Needs Working Group, 1996, 'Skills for the new millennium: CanMEDS 2000 project', Annals of the Royal College of Physicians and Surgeons in Canada 29, 206-216.

Strauss, D.F.M., 2009, Philosophy: Discipline of the disciplines, Paideia Press, Grand Rapids.

VWS, 2002, 'De arts van straks. Een nieuw opleidingscurriculum. Ministerie van Volksgezondheid, Welzijn en Sport', Den Haag.

VWS \& OCW, 2003, 'De zorg van morgen: Flexibiliteit en samenhang, Ministerie van Volksgezondheid, Welzijn en Sport en Ministerie van Onderwijs, Cultuur en Wetenschappen', Den Haag.

Wolters, A.M., 1985, Creation regained: Biblical basics for a reformational worldview, Eerdmans, Grand Rapids.

Woodbridge, K., \& Fulford, K.W.M., 2004, Whose values? A workbook for values-based practice in mental health care, Sainsbury Centre for Mental Health, Sainsbury. 